\title{
INTERNALISASI NILAI-NILAI PENDIDIKAN AGAMA ISLAM PADA KEGIATAN EKSTRAKURIKULER ROHANIAH ISLAM DALAM MEMBINA KARAKTER PESERTA DIDIK DI SMA NEGERI 1 AIR PUTIH KECAMATAN AIR PUTIH KABUPATEN BATU BARA
}

\author{
Nuraini* \\ *Mahasiswa S2 PAI FITK UIN Sumatera Utara
}

\begin{abstract}
The purpose of this study is to describe the implementation of the internalization of Islamic religious values through Islamic spiritual extracurricular activities in SMA Negeri 1 Air Putih, and to describe the supporting factors and obstacles. From the results of the study it can be concluded that the process of internalizing Islamic religious SMA Negeri 1 Air Putih Islamic spiritual extracurricular activities in high school uses two ways namely direct (exemplary, habituation, supervision, advice, and punishment) and indirect (classroom learning). And there are four stages, namely giving knowledge, understanding, refraction, and internalization. Supporting factors include the majority of students coming from religious and active families studying at the diniyah madrasa, the availability of infrastructure and other supporting equipment. While the inhibiting factor is each student has a different background, some teachers who are less active in participating in Islamic spiritual extracurricular activities and the saturation of students in participating in Islamic spiritual extracurricular activities.
\end{abstract}

Keywords: Internalization, Islamic Values, and Spiritual Extracurricular Islam.

\section{PENDAHULUAN}

Dalam Islam, disamping pendidikan Islam, anak juga harus menerima pendidikan akhlak atau moral sebagai bahagian dari pendidikan Islam. Merujuk kepada As-Syahid akhlak merupakan fondasi yang utama dalam pembentukan kepribadian manusia yang seutuhnya. Pendidikan yang mengarah kepada terbentuknya pribadi berakhlak merupakan hal pertama yang harus dilakukan sebab akan melandasi kestabilan kepribadian manusia secara keseluruhan. Berarti muara Pendidikan Islam adalah akhlak yang baik. Al-Ghazali menawarkan keutamaan rohaniyah bisa dicapai dengan tertanamnya akhlak yang baik (husna-khuluq). Agama Islam memberikan dengan lengkap tentang cara pembinaan akhlak dalam keluarga baik pembinaan akhlak orang tua 
maupun akhlak anak- anak mereka. Agama Islam telah memantapkan dasar yang kokoh dalam pembinaan akhlak di rumah tangga dengan landasan tauhid sehingga menjadikan tauhid sebagai landasan dan sumber energi bagi akhlak keluarga.

Penguatan pendidikan karakter dalam konteks sekarang sangat relavan untuk mengatasi krisis moral yang sedang terjadi di negara kita. Diakui atau tidak diakui saat ini terjadi krisis yang nyata dan mengkhawatirkan dalam masyarakat dengan melibatkan milik kita yang paling berharga, yaitu anak- anak. Krisis itu antara lain berupa meningkatnya, maraknya angka kekerasan anak- anak dan anak, kejahatan terhadap teman, kebiasaan menyontek. Pencurian, perampasan, dan perusakan milik orang lain sudah menjadi masalah sosial yang hingga saat ini belum dapat diatasi secara tuntas. Perilaku anak kita juga diwarnai dengan gemar menyontek, kebiasaan bullying di sekolah, dan tawuran.

Cara alternatif untuk mengatasi semua persoalan tersebut adalah dengan menanamkan nilai- nilai akhlakul karimah kepada peserta didik. Seorang guru harus mengetahui karakter murid, guru harus selalu berusaha meningkatkan keahliannya, baik dalam bidang yang diajarkannya maupun dalam cara mengajarkannya, guru harus mengamalkan ilmunya, jangan berbuat berlawanan dengan ilmu yang diajarkannya. Seorang guru terutama ayah dan ibu mempunyai tanggung jawab sangat besar dalam mendidik anak-anak dengan kebaikan dan dasar dasar moral. Tanggung jawab perbaikan jiwa mereka, mendidik anak- anak. Internalisasi (internalization) adalah suatu proses memasukkan nilai atau memasukkan nilai atau memasukkan sikap ideal yang sebelumnya dianggap berada di luar, agar tergabung dalam pemikiran seseorang dalam pemikiran, keterampilan dan sikap pandang hidup seseorang. Internalisasi dalam pengertian dimaksud, dapat pula diterjemahkan dengan pengumpulan nilai atau pengumpulan sikap tertentu agar terbentuk menjadi kepribadian yang utuh.

\section{KAJIAN TEORETIS}

Reber sebagaimana dikutip Mulyana (2004) menjelaskan, internalisasi diartikan sebagai menyatunya nilai dalam diri seseorang, atau dalam bahasa psikologi merupakan penyesuaian keyakinan, nilai, sikap, praktik dan aturan- aturan baku pada diri seseorang. Ihsan (2007) memaknai internalisasi sebagai upaya yang dilakukan untuk memasukkan nilai- nilai ke dalam jiwa sehingga menjadi miliknya. 
Internalisasi nilai-nilai pendidikan Islam yang bersumber pada Alquran dan Sunnah merupakan ruhnya perguruan tinggi Islam khususnya, oleh sebab itu cara dan bentuk pendidikan seyogisanya dengan mengembangkan dan memberikan kesadaran terhadap mahasiswa terkait nilai-nilai islami seperti kejujuran, kebersihan, lemah-lembut, kasih-sayang, kebaikan, kebijakan, kebenaran, keikhlasan, kesabaran, dan lain sebagainya.

Nilai dalam bahasa Inggris adalah "value", dalam bahasa latin disebut "velere", atau bahasa Prancis Kuno "valoir". Nilai dapat diartikan berguna, mampu akan, berdaya, berlaku, bermanfaat, dan paling benar menurut keyakinan seseorang atau sekelompok orang. (Adisusilo, 2012) Kamus Besar Bahasa Indonesia nilai diartikan sebagai sifat-sifat (hal) yang penting atau berguna bagi kemanusiaan atau sesuatu yang menyempurnakan manusia. Sehingga nilai merupakan kualitas suatu hal yang menjadikan hal yang disukai, diinginkan, dikejar, dihargai, berguna, dan suatu yang terpenting atau berharga bagi manusia sekaligus inti dari kehidupan. (Tim Penyusun Kamus Pusat Bahasa, Kamus Besar Bahasa Indonesia, 2005: 783) Nilai dapat diartikan sebagai suatu tipe kepercayaan yang menjadi dasar bagi seseorang maupun sekelompok masyarakat, dijadikan pijakan dalam tindakannya, dan sudah melekat pada suatu sistem kepercayaan yang berhubungan dengan manusia yang meyakininya

Pendidikan islam itu adalah pembentukan kepribadian muslim (Darajat, dkk, 1992). Pendidikan agama Islam keseluruhan dari ajaran agama Islam yang dibawa oleh Nabi Muhammad saw. yang meliputi hubungan manusia dengan Allah, dengan sesama manusia, dengan dirinya, dan dengan alam sekitarnya. Dalam penjabarannya meliputi akidah, syariah, dan akhlak (Namsa, 2000). Al-Syaibani (1979) mengartikannya sebagai "usaha pendidikan untuk mencapainya, baik pada tingkah laku individu dan pada kehidupan pribadinya atau pada kehidupan masyarakat dan pada kehidupan alam sekitar pada proses kependidikan.

Pendidikan Agama Islam (PAI) dapat diartikan sebagai program yang terencana dalam menyiapkan peserta didik untuk mengenal, memahami, menghayati, hingga mengimani ajaran Agama Islam, serta diikuti tuntunan untuk menghormati penganut agama lain dalam hubungannya dengan kerukunan antar untuk beragama hingga terwujud dapat diartikan sebagai program yang terencana dalam hubungannya dengan kerukunan antar umat beragama hingga terwujud kesatuan dan persatuan bangsa. Serta bertujuan untuk menyiapkan siswa dalam 
menyakini, memahami, menghayati, dan mengamalkan ajaran Islam melalui kegiatan bimbingan, pengajaran dan latihan (Amin, 2006).

Muhaimin (2007 menjelaskan karakteristik PAI antara lain: (1) PAI berusaha menjaga akidah peserta didik agar tetap kokoh dalam situasi dan kondisi apapun, (2) PAI berusaha menjaga dan memelihara ajaran dan nilai-nilai yang tertuang dan yang terkandung dalam Alquran dan alsunnah serta otentisitas keduanya sebagai sumber utama ajaran Islam, (3) PAI menjadi landasan moral dan etika dalam pengembangan iptek dan budaya serta aspek- aspek kehidupan lainnya, (4) substansi PAI mengandung entitas-entitas yang bersifat rasional dan supra rasional, (5) PAI berusaha menggali, mengembangkan dan mengambil ibrah dari sejarah dan kebudayaan (peradaban) Islam., dan (6) dalam beberapa hal, PAI mengandung pemahaman dan penafsiran yang beragam, sehingga memerlukan sikap terbuka dan toleran atau semangat ukhuwah Islamiyah

\section{METODOLOGI PENELITIAN}

Penelitian ini dilaksanakan di SMA Negeri 1 Air Putih Kecamatan Air Putih Kabupaten Batubara. Pendekatan penelitian ini menggunakan metode kualitatif. Sumber data dalam penelitian ini adalah: (1) data primer diperoleh dari hasil wawancara dengan informan yaitu, kepala madrasah, pembina Rohis, pembantu kepala sekolah dibidang kurikulum, dan siswa, (2) sumber data sekunder diperoleh dari buku, arsip, serta dokumentasi. Teknik pengumpulan data teknik observasi, teknik wawancara, catatan lapangan dan dokumen-dokumen. Prosedur pelaksanaan penelitian dilakukan dengan cara mereduksi data, menyajikan data dan membuat kesimpulan. Teknik penjaminan keabsahan data dilakukan dengan kredibilitas, transferabilitas, dependablitas dan konfirmabilitas.

\section{HASIL PENELITIAN DAN PEMBAHASAN}

Nilai-nilai PAI yang diinternalisasikan melalui kegiatan Ekstrakurikuler Rohis di SMA Negeri 1 Air Putih di antaranya sebagai berikut:

1. Nilai Pendidikan I'tiqädiyah berkaitan dengan ketaatan, membiasakan diri membaca doa-doa harian, membaca Asmā'ulHusna, serta tadarus Al-Qurān yang dilaksanakan setiap hari Jum'at. Ini menunjukkan ketaatan untuk percaya dan iman kepada Allah SWT bahwa tidak ada kekuatan yang bisa menandingi 
kekuatan-Nya, serta dengan berdo'a membuktikan akan pengabdian kepada Allah, hal tersebutlah yang ditunjukkan oleh siswa-siswi..

2. Pendidikan Ibadah. berhubungan dengan ibadah adalah nilai yang dikaitkan dengan konsep, sikap, dan keyakinan yang memandang berharga terhadap ibadah dalam rangka pendekatan diri kepada Allah SWT. Nilai ubudiyah mencakup rukun Islam. Seperti syahadat, shalat, zakat, puasa, dan haji. Dalam mewujudkan nilai pendidikan ibadah maka dilaksanakan kegiatan shalat Zuhur berjamaah, shalat sunnah Duha, shalat jum'at berjamaah, latihan menyembelih hewan qurban, dan peringatan hari besar Islam, karena mereka percaya bahwa di samping mereka mencari ilmu juga memiliki kewajiban beribadah dan mencari ridha Allah SWT. Pelaksanaan untuk penanaman ibadah kepada anak melalui kegiatan pada bulan Ramadhan di SMA Negeri 1 Air Putih diadakan kegiatan latihan zakat, pengumpulan zakat dikelola oleh Rohis bersama dengan OSIS yang selanjutnya didistribusikan kepada mustahik zakat di sekitar SMA Negeri 1 Air Putih. Kegiatan shalat berjamaah rutin dilaksanakan setiap hari pada saat waktu zuhur. Anggota Rohis saling mengingatkan antar teman, guru PAI secara rutin mengingatkan siswanya untuk shalat zuhur ketika melewati sekumpulan siswa. Pada kegiatan shalat Jum'at diadakan sweeping untuk memastikan seluruh siswa putra melaksanakan serangkaian kegiatan shalat Jum'at.

3. Nilai yang berhubungan dengan muamalah adalah nilai yang dikaitkan dengan konsep, sikap, dan keyakinan yang memandang berharga hubungan antara manusia dengan manusia, manusia dengan alam sekitar, atau hubungan dengan lingkungan sosial. Agar peserta didik mengerti apa artinya saling tolong menolong. Adapun nilai ini ditunjukkan oleh Rohis SMA Negeri 1 Air Putih melalui latihan zakat fitrah yang dilaksanakan setiap bulan Ramadhan.

4. Pendidikan Siyāsah berkaitan dengan aturan, dan keteraturan menyangkut masalah- masalah kemasyarakatan (politik) diantaranya: persaudaraan, musyawarah, toleransi, tanggung jawab dan lain-lain. Nilai-nilai keagamaan yang diterapkan dalam nilai siyāsah yakni dengan musyawarah demi terwujudnya sebuah kesepakatan. Nilai tanggung jawab dapat terlihat dengan mereka selalu mengerjakan sesuatu yang ditugaskan melalui 
program kerja dengan sungguh-sungguh, ini membuktikan bahwa mereka selalu bertanggung jawab dalam melaksanakan kewajiban. Toleransi yang diaplikasikan oleh Rohis yakni dengan mereka menerima dan menghargai pendapat dari orang lain pada waktu rapat. Siyāsah (politik) yang dilakukan oleh Rohis SMA Negeri 1 Air Putih yakni dengan latihan demokrasi dalam wujud pemilihan ketua Rohis yang dilakukan dengan pemaparan visi-misi calon, dan pemungutan suara. Persaudaraan yang terjalin di antara anggota Rohis terlihat dengan diadakannya diskusi, kajian, mentoring, serta tolong menolong dalam hal kebaikan. Dengan pembiasaan dan keteladanan dalam keagamaan dapat menciptakan kesadaran beragama. Mereka akan merasa bahwa Allah akan selalu hadir didalam dirinya, mengawasi gerak geriknya. Sehingga di dalam dirinya akan tertanam selalu megerjakan sesuatu yang sejalan dan mengharap ridho Allah SWT.

5. Nilai Pendidikan Khuluqiyah adalah nilai yang peranannya terpenting dalam kegiatan rohis, dikarenakan berhasil tidaknya akhlak peserta didik dalam mengikuti kegiatan Rohis. Nilai pendidikan ini merupakan nilai pendidikan yang berkaitan dengan etika (akhlak) yang bertujuan membersihkan diri dari perilaku rendah dan menghiasi diri dengan perilaku terpuji. Dimensi ini meliputi antara lain bekerjasama, kasih sayang, berlaku jujur dan amanah, dan disiplin.

Metode pelaksanaan kegiatan ekstrakurikuler rohis dalam membina karakter peserta didik SMA Negeri 1 Air Putih adalah:

1. Metode Uswah atau Keteladanan. Metode ini sangat efektif untuk menanamkan nilai-nilai akhlak, di sini guru menjadi panutan utama bagi murid-muridnya dalam segala hal. Adapun metode keteladanan yang dilakukan di SMA Negeri 1 Air Putih, misalnya: kasih sayang seorang guru, senyum, ceria, lemah lembut dalam berbicara, disiplin beribadah, Rapi, Ramah dan tentunya bertingkah laku yang baik yang dilakukan oleh guru akan dicontoh oleh siswa - siswinya. Metode keteladanan merupakan salah satu metode yang paling sukses dalam penanaman akhlakul karimah bagi peserta didik, karena peserta didik meniru dari apa yang dilihat dan didengar, bukan sekedar nasihat. Misalnya dalam sopan santun antara pendidik di SMA Negeri 1 Air Putih, tutur kata pendidik yang kemudian ditiru oleh peserta didik, ketika 
bertemu bersalaman, sopan, santun, sapa, dan senyum. Peserta didik pada tingkat dasar sangat membutuhkan contoh atau dari orang tua ataupun pendidik, sebab pada masa ini merupakan masa peniruan bagi peserta didik untuk mencari sosok atau figur yang diinginkan.

2. Metode Ceramah. Metode ceramah merupakan metode yang paling sering digunakan dalam pembelajaran PAI, melalui metode ceramah ini guru menyampaikan materi pelajaran secara lisan. Peran siswa hanya mendengarkan penjelasan guru dengan teliti serta mencatat hal- hal penting yang disampaikan oleh guru. Bagi guru Agama Islam, metode ceramah cukup mudah untuk dipersiapkan dan dilaksanakan. Metode ini juga tidak memerlukan waktu yang lama dalam menjelaskan materi pelajaran dan tidak menggunakan alat peraga. Tetapi metode ceramah memiliki kelemahan dalam pelaksanaanya, antara lain siswa menjadi pasif karena hanya mendengarkan penjelasan guru selama proses pembelajaran, materi yang dikuasai hanya sebatas yang disampaikan oleh guru dan siswa tidak berkesempatan mengeluarkan pedapat dan mengembangkan cara berpikirnya.

3. Metode Tanya Jawab. Metode tanya jawab adalah penyampaian pelajaran dengan cara guru mengajukan beberapa pertanyaan yang akan dijawab oleh siswa atau sebaliknya. Metode ini lebih mengaktifkan suasana kelas dibandingkan dengan metode ceramah. Siswa akan lebih muda dalam memahami materi pelajaran karena guru memberikan kesempatan kepada siswa untuk menanyakan materi yang belum jelas. Dan melalui metode ini, guru melatih keberanian siswa dalam bertanya dan mengemukakan pendapat mereka. Pelaksanaan metode tanya jawab ini membutuhkan waktu yang lebih lama. Pertanyaan yang diajukan oleh siswa terkadang tidak sesuai dengan materi pelajaran yang disampaikan oleh guru. Dan bagi siswa yang tidk terbiasa dalam kegiatan tanya jawab akan bersikap diam dan mendengarkan.

4. Metode Diskusi. Diskusi merupakan kegiatan yang dilakukan dalam kelompok untuk memecahkan suatu masalah atau membahas suatu topik tertentu untuk mengambil kesimpulan. Guru menggunakan metode diskusi ini bertujuan untuk merangsang siswa menjadi aktif dalam memberikan gagasan yang mereka miliki, melatih siswa untuk bertukar pikiran dengan orang 
lain, malatih keberanian siswa untuk mengemukakan pendapatnya dan melatih siswa untuk menghargai pendapat orang lain.

5. Metode Kerja Kelompok. Metode kerja kelompok merupakan metode mengajar dengan mengelompokkan siswa menjadi beberapa kelompok untuk bekerja sama dalam menyelesaikan tugas yang ddiberikan oleh guru.

6. Metode Demonstrasi. Metode demonstrasi adalah suatu cara penyajian materi pelajaran dengan cara menunjukan proses pelaksanaan materi yang disajikan tersebut secara langsung di depan siswa sehingga siswa dapat menyaksikan secara langsung dan dapat dipahami dan ditiru.

7. Metode Qishah atau Cerita. Metode Qishah atau cerita adalah metode yang digunakan menyampaikan sebuah nilai akhlak melalui sebuah cerita sehingga melalui cerita tersebut seorang anak akan mengetahui bagaimana pesan yang disampaikan. Metode ini sangat disukai anak sehingga anak cenderung lebih senang dan memperhatikan sehingga nilai yang dikehendaki dapat mengena dengan baik di hati siswa. Dalam pembelajaran ini guru menceritakan kisah- kisah Nabi kepada peserta didik terlihat tertarik dan mendengarkan dengan baik cerita yang disampaikan oleh guru. Setelah selesai bercerita guru bertanya kepada siswa tentang materi yang disampaikan dan hampir seluruh siswa antusias menjawab yang berarti mereka mengerti maksud dari cerita tersebut.

Upaya Penanaman nilai- nilai akhlakul karimah dalam membentuk karakter siswa melalui pembelajara Agama Islam di SMA Negeri 1 Air Putih. Bukan merupakan kegiatan yang mudah. Dalam perwujudannya memerlukan banyak faktor pendukung untuk memperoleh hasil yang optimal dalam membentuk peserta didik yang berkarakter. Beberapa faktor pendukung dalam penanaman nilai- nilai pendidikan karakter dalam pembelajaran Pendidikan Agama Islam, diantaranya seperti yang dituturkan kepala sekolah sebagai berikut:

1. Faktor internal adalah faktor yang berasal dari diri siswa itu sendiri. Faktor yang mempengaruhi internalisasi nilai-nilai Pendidikan Agama Islam di SMA Negeri 1 Air Putih adalah terkadang motivasi dari dalam diri mereka yang kadang naik turun. Baik itu dari diri pengurus Rohis maupun siswa yang lain. Faktor motivasi ini harus selalu diperhatikan oleh pembina dan pengurus Rohis, agar pengurus Rohis selalu bersemangat dalam 
menyelenggarakan program-programnya dengan baik dan tetap bersemangat untuk selalu mencari ilmu yang nantinya akan ditularkan kepada kawan-kawannya yang lain. Hal yang perlu diperhatikan pula adalah memotivasi siswa lain agar tertarik dan semangat dalam mengikuti kegiatan-kegiatan yang diadakan oleh Rohis, sehingga proses internalisasi nilai-nilai Pendidikan Agama Islam tidak terhambat oleh sepinya peserta yang mengikuti kegiatan Rohis.

2. Faktor eksternal adalah faktor yang berasal dari luar diri peserta didik. Faktor eksternal yang dialami Rohis adalah: Faktor keluarga, Keluarga merupakan lingkungan pertama dan utama bagi anak. Faktor yang berkaitan dengan keluarga adalah terkadang setelah pulang sekolah tidak ada kontrol dari orang tua, orang tua berpikiran bahwa anak jika sudah disekolahkan perilakunya akan baik, pemikiran yang seperti ini akan menghambat peserta didik untuk terus menerus (continue) mengamalkan nilainilai Pendidikan Agama Islam. Selain itu, sebagian orang tua siswa SMA Negeri 1 Air Putih yang cenderung berorientasi kepada prestasi kognitif siswa sehingga terkadang sulit untuk mengizinkan anaknya mengikuti kegiatan ekstrakurikuler yang tidak berkaitan langsung dengan nilai ulangan atau nilai rapor.

3. Faktor lingkungan. Faktor lingkungan disini terbagi menjadi lingkungan sekolah dan lingkungan masyarakat. Di lingkungan sekolah terkadang pendidik belum sepenuhnya bisa menjalankan fungsinya sebagai pendidik, seperti kurang tepat waktu dalam memasuki ruangan, atau mengakhiri pembelajaran lebih awal. Ini akan berdampak pada pola peserta didik yang tidak disiplin. Teman sejawat sering mendorong untuk berbuat yang menyimpang dari norma-norma agama dan masyarakat. Contohnya membuang sampah tidak pada tempatnya, bujukan untuk merokok, membolos sekolah, dan lain sebagainya. Lingkungan masyarakat, peserta didik yang tinggal di lingkungan baik secara tidak langsung akan mengikuti untuk berbuat baik, akan tetapi jika tinggal dilingkungan yang kurang baik, kemungkinan akan memengaruhi cara berfikir dan perilakunya juga. Sebagian besar peserta didik SMA Negeri 1 Air Putih tinggal di daerah perkotaan, sehingga lingkungannya tidak begitu memperhatikan perkembangan kepribadiannya. Misalnya, orang tua tidak memerhatikan pergaulannya, rutinitas 
harian dan ibadahnya. Hal ini menghambat usaha pembentukan kepribadian Islami yang telah diupayakan SMA Negeri 1 Air Putih melalui Rohis.

4. Faktor teknologi. Tidak bisa dipungkiri bahwa sekarang telah masuk pada dunia IPTEK dalam bidang pertukaran informasi tentu akan menciptakan penukaran informasi semakin global, melalui handphone, internet, televisi, serta audio lainnya. Hal ini akan menciptakan komunikasi bebas lintas daerah, juga dapat menjadi alat untuk mengajari atau bahkan sebaliknya merusak tatanan nilai- nilai spiritual keagamaan seseorang. Media internet yang begitu canggih, dapat mengakses berbagai situs, dari situs pendidikan hingga situs yang tidak baik. Serta media sosial seperti facebook, twitter, BBM, instagram, dan lain sebagainya. Juga dapat memengaruhi pemikiran serta tindakan peserta didik. Dampak terkecil yang paling terasa bagi siswa usia SMA adalah tidak bisa membagi waktunya antara belajar, kegiatan siswa, dan komunikasi. Mereka cenderung lebih asyik bermain HP ketimbang fokus kepada pekerjaan yang ada di depannya.

Banyak faktor pendukung dalam pembelajaran, akan tetapi tidak menutup kemungkinan adanya faktor penghambat diantaranya sebagai berikut:

1. Faktor internal adalah faktor yang berasal dari diri siswa itu sendiri. Terkadang motivasi di dalam diri mereka pun yang kadang terjadi naik turun. Baik itu dari diri pengurus rohis maupun siswa yang lain. Faktor motivasi ini harus sering diperhatikan oleh pembina rohis, agar pengurus rohis bersemangat dalam menyelenggarakan program-progranya dengan baik dan bersemangat untuk selalu mencari ilmu yang nantinya akan ditularkan kepada kawan-kawannya yang lain.

2. Faktor eksternal adalah faktor yang berasal dari luar peserta didik yang dialami rohis. Adapun faktor tersebuat ialah merupakan Latar belakang keluarga yang berbeda, sehingga tidak menutup kemungkinan tidak semua peserta didik belajar agama di rumah. Potensi baik pemahaman, motivasi, minat, masalah, kondisi, dan sikap yang dimiliki oleh setiap peserta didik berbeda- beda. Selanjutnya ketika pembelajaran di rohis tidak tersedianya media pembelajaran yang lengkap sehingga kurangnya minat peserta didik mengikuti rohis dan keadaan psikologi peserta didik sulit untuk menerima pembelajaran dengan baik, karena disebabkan 
lahirnya berbeda-beda dan troma karena kondisi kelurga yang berbeda- beda. Kemudian pemilihan metode yang kurang tepat pada saat pembelajaran sehingga membuat peserta didik enggan merespon atau ikut aktif dalam kegiatan belajar mengajar yang sedang berlangsung. Meskipun terdapat beberapa faktor penghambat dalam penanaman nilai-nilai pendidikan karakter dalam pembelajaran Pendidikan Agama Islam, namun hal tersebut dapat diatasi oleh pendidik dengan baik.

Upaya dalam mengatasi Hambatan kegiatan Ekstrakurikuler Rohis di SMA Negeri 1 Air Putih adalah menjelasakn terlebih dahulu kepada kedua orang tua yang anaknya mengikuti kegiatan Rohis agar tidak terjadi kesalah paham dengan adanya isu -isu diluar sana mengenai kajian Islam ini, yang sekang kita lihat banyaknya fitnah dari berbagai kalangan. Memeberikan Potensi baik pemahaman, motivasi, minat, masalah, kondisi, dan sikap yang dimiliki oleh setiap peserta didik berbeda- beda. Memberikan media pembelajaran agar mempermudah mendapatkan informasi.

Memahami keadaan psikologi peserta didik sulit untuk menerima pembelajaran dengan baik, karena disebabkan lahirnya berbeda-beda dan troma karena kondisi kelurga yang berbeda- beda. Kemudian dapat memilih pemilihan metode yang tepat pada saat pembelajaran sehingga membuat peserta didik enggan merespon atau ikut aktif dalam kegiatan belajar mengajar yang sedang berlangsung. Memotivasi peserrta didik agar semangat menjalankan kegiatan ektrakurikuler rohis karena di dalam diri mereka pun kadang terjadi naik turun. Baik itu dari diri pengurus rohis maupun siswa yang lain. Motivasi ini harus sering diperhatikan oleh pembina rohis, agar pengurus rohis bersemangat dalam menyelenggarakan program-progranya dengan baik dan bersemangat untuk selalu mencari ilmu yang nantinya akan ditularkan kepada kawankawannya yang lain. Kemudian, melakukan pendekatan yang mana pendekatan merupakan hal terpenting di suatu kegiatan ekstrakurikuler sekolah, baik pendekatan individual maupun kelompok.

\section{SIMPULAN}

Simmpulan yang dapat ditarik adalah: (1) pelaksanaan kegiatan ekstrakurikuler Rohisdi dilakukan dengan keorganisasian, melalui keteladanan, pembiasaan serta adanya metode dan strategi yang dilakaukan untuk mencapai tujuan yang di harapkan agar peserta didik mampu merealisasikan di luar sekolah atau di lapangan. Banyaknya 
materi yang di sajikan dan praktek yang di jalankan bertujuan untuk menambah khazannah baik peserta didik maupun guru, (2) peranan nilainilai akhlakul karimah dalam membina karakter siswa di SMA adalah menciptakan kader-kader Islam yang berakhlak mulia dan berbudi pekerti luhur, (3) faktor pendukung dalam pelaksanaan Rohis adalah sarana prasarana, pengadaan media pembelajaran seperti leptop, lcd/proyektor, literasi buku-buku, masjid dan sebagainya telah ada disamping itu dukungan pihak sekolah/lingkungan, dukungan kepala sekolah, para guru dan staf lainnya akan menunjang terlaksananya program Rohis yang berdampak pada pengembangan diri siswa. Di lain pihak adalah kebutuhan manusia akan agama, dapat dilihat dari tujuan para anggota Rohis dalam mengikuti kegiatan Rohis. Mengingat agama islam sebagai pedoman hidup manusia. Dengan mengikuti Rohis, tentunya memiliki berbagai manfaat yang dapat diaplikasikan dalam kehidupan sehari-hari khususnya yang berkaitan dengan kerohanian, (4) faktor kegiatan Rohis waktu, seringkali waktu yang bersamaan akan mempengaruhi keaktifan siswa untuk mengikuti kegiatan Rohis yang dapat mengembangkan sikap religius siswa dan dana dan anggaran, dana yang ada berasal dari sekolah, sponsor dari pembuatan proposal kegiatan, dan juga infaq siswa yang diadakan pada hari Jumat.

\section{REKOMENDASI}

Rekomendasi yang dapat penulis berikan kepada: (1) kepada Kepala Sekolah hendaknya diusahakan pihak sekolah untuk memberikan waktu yang optimal terhadap keagamaan. Di samping itu Kepala sekolah bekerjasama dengan wali murid untuk menginternalisasikan nilai-nilai Pendidikan Agama Islam, (2) kepada Pembina aagar berperan sebagai pembina Rohis yang lebih baik lagi dan memberikan inovasi metode pembelajaran sehingga dapat meningkatkan minat keikutsertaan siswa dalam Rohis, dan (3) kepada Peserta Rohisagar seebaiknya lebih aktif lagi dalam mengikuti berbagai kegiatan Rohis. Lebih memperhatikan setiap materi yang disampaikan oleh pembina/ustdzah, dan bertanya ketika belum memahami perihal materi tersebut. 


\section{DAFTAR PUSTAKA}

Al Rasyidin. (2008) Falsafah Pendidikan Islam Membangun Kerangka Ontologi Epistimologi, dan Aksiologi Praktik Pendidikan. Bandung: Citapustaka Media.

Al-Syaibany, (1979) Falsafah al-Tarbiyyah al- Islamiyyah,. Alih Bahasa: Hasan Langgulung, Falsafah Pendidikan Islam. Jakarta: Bulan Bintang.

Daradjat, Zakariah, dkk. (1992). Ilmu Pendidikan Islam. Jakarta: Bumi Aksara.

Gunawan, Heri. (2012). Pendidikan Karakter, Jakarta: Alfabeta.

Husnel Anwar.Al Islam, (2009), Pendidikan Agama Islam Untuk Perguruan Tinggi, Bandung:citapustaka.

Ihsan, Fuad Hamdani. (2007). Filsafat Pendidikan Islam, bandung: Pustaka setia.

Kaelani, Syarif. (2007). Perkembangan Peserta Didik. Medan: Unimed Press. Marzuki. (2014). Pendidikan Karakter Islam, Yogyakarta: Amzah.

Masganti. (2012), Metode Penelitian Pendidikan Islam, Medan: IAIN PRESS.

Miswar, dkk. (2015). , Akhlak Tasawuf Membangun Karakter Bangsa, Medan: Perdana Publishing.

Moleong, Lexy J. (2009). Metodologi Penelitian Kualitatif. Bandung: Rineka Cipta

Rusydi Ananda dan Amiruddin. (20170 Inovasi Pendidikan. Melejitkan Potensi Teknologi dan Inovasi Pendidikan. Medan: Widya Puspita.

Sani, Ridwan Abdullah dan Kadir, Muhammad. (2016), Pendidikan Karakter Mengembangkan Karakter Anak yang Islami, Jakarta: Bumi Aksara

Syafari, Amri Ulil. (2012), Pendidikan Karakter Berbasis Alquraan, Jakarta: Raja Grafindo Persada.

Yaumi, Muhammad. (2014) Pendidikan Karakter: Landasan Pilar, Dan Implementasi, Jakarta: Prenadamedia Group 